\title{
Measuring Sponsorship Return on Investment (ROI) for Sponsors in the field of sport in Egypt
}

\section{Dr/ Ahmed Fathy Husain Alafandi ${ }^{1}$}

\section{Background:}

Over the last two decades sport sponsorships have matured to play a dominant role in many organizations' promotional mix. Conversely, many sport organizations, sport event managers, leagues and even individual athlietes see lavish corporate spending as the most viable, if not the only, path to profitability (20). The unique role sport sponsorship plays for sport marketers is also evidenced by many researchers $(1 ; 20 ; 3)$. However, while from the perspective of the recipient, sponsorship acquisition is a strategic tool with immediate implications for the organization's (or events, leagues, etc.) bottom line, from the perspective of the sponsor, sponsorships have mostly been considered as one tactical component among others in the company's larger integrated marketing communications strategy (13; 14).
In addition, corporations have become increasingly sophisticated consumers of sport sponsorships, demanding from their partners to develop more complete sponsorship packages $(5 ; 9)$. Based on the sponsor's designation of the target market, event sponsorships, for example, may incorporate traditional communication vehicles such as mass advertising, promotions, point-of-purchase merchandising, cross-selling opportunities, and public relations as well as nontraditional Internet-based techniques, including online games and event-specific communities (4; 6). Hence, unless marketers of sport sponsorships continuously add value to their product, they will see their share in the corporate communication budget dwindle in the future.

As the content of sponsorship packages changes, so does the need for measuring

${ }^{1}$ Lecturer, Department of Sports Management, Benha University. 
effectiveness (5). Yet, in comparison to modern datadriven direct, one-on-one, and relationship techniques, marketing represents a crude marketing tool because return on investment is notoriously difficult to measure (13). Even a seemingly simple task such as comparing brand awareness between sport fans and nonfans poses myriad problems (8). Linking sport sponsorship dollars to product sales is infinitely more complicated. But as companies feel the pressure to justify large sponsorship investments to employees, investors, clients, and trade partners, proof that brand equity and financial objectives are being achieved is needed (15). Clients increasingly demand evidence that links fungible deliverables like sales volume and stock price more or less directly to their investment in the sponsorship

Accountability is the key and recipients must therefore do whatever they can to support clients in their effort to justify the sponsorship (11)

The challenge for sport marketers is to represent their sport organizations to potential sponsors and to sell their assets in an increasingly competitive global marketplace is tremendous. Two relatively new forces add additional layers of complexity to the business of sport sponsorship: the Internet2 and what has been called the globalization of markets $(10 ; 17 ; 16)$.

To succeed in this brave new world of global ebusiness, sport marketers must understand what threats the Internet poses to sport esponsoring and what opportunities may open up with this new medium. Hence, before integrating the Internet into a sport sponsorship package for a global market, marketers need to be able to judge whether the personality of the sponsor's brand aligns well with the Internet and if the Internet fits with the target audience (17).

In addition, marketers need to understand how to coordinate an online strategy with an offline strategy and whether the objective of using the Internet for sponsorship purposes is the creation of brand awareness, exploration, or commitment (21). Beyond such conventional questions about the medium, marketers of global sport sponsorship packages must be sensitized to 
its unique characteristics, in particular its ability to aggregate global consumers and to create the conditions of possibility for intimate consumer relationships (18).

Sponsors of various sporting events are struggling to seize the opportunity to provide statistics demonstrating that sponsorship is not a frivolous expense, but a means to generate business. Business owners continually invest in a suite of marketing services that provide value for their clients. One of those key services is sponsorship research and ROI measurement.

The field of sponsorship ROI has matured to help companies save money and build business, something CEOs and shareholders all demand, so why aren't more companies investing in consulting and research information to help optimize the ROI of their sponsorships?

\section{Review of literature:}

Henseler, J, Wilson, B and Westberg, K (2011) examined how sponsors perceive the impact of different elements of a sponsorship package on brand equity. An empirical study using an online survey was conducted among key managers involved in sponsoring football clubs in the Netherlands. They developed a formative

measure sponsorship, termed the Sport Sponsorship Index, and linked this measure with brand equity. Results indicated that the various facets of a sport sponsorship package, such as exposure of the brand and coverage of the sport, are perceived by sponsors to contribute differently to the impact on brand equity. Within sponsorship negotiation, these findings assist all parties in understanding the relative importance of the elements of a sponsorship in fulfilling brandrelated objectives. By constructing and validating an adequate scale of the key components incorporated into a sponsorship package, we provide sport administrators with item level diagnostics which can contribute to improving their sponsorship offering. (8)

Kim, J. W. (2010) investigated the relationship between sports-related event sponsorship and stock market valuation and identifies factors that influence the financial rewards of sponsorship using World Cup and PGA tour sponsorship data. In particular, relationship between sports sponsorship with financial performance is examined in 
terms of sponsorship fit, event characteristics, and brand equity. Event study results show that sponsorship for World Cup and PGA is positively related to abnormal stock returns for sponsors but not every sponsor enjoys significantly positive cumulative abnormal returns. Regression analysis indicates that unexpectedly brand equity and U.S. country of origin is negatively associated with financial performance. However, U.S. sponsors with top brand value boost their abnormal stock return. Product fit enhances short-term financial performance but the significant impact of event type on financial outcome was not observed. (11)

By investigating the personality congruence between brands and sporting events, Lee, H. S., \& Cho, C. H. (2009) explored which brands and sporting events fit together best. The results of this survey, which included 373 student-subjects, showed that the pairing of "sincerity" brands and "diligence" sporting events yielded the best brand-event personality fit and sponsorship effectiveness. Through structural-relationship testing, this study confirmed that the personality congruence between a sponsoring brand and a sporting event was the most significant attitude predictor toward the sponsoring brand. (12)

Cunningham, S., Cornwell, T. B., \& Coote, L. V. (2009) described a corporate identity sponsorship policy link and offered empirical support for it via a mixed method research design. Content analysis of 146 Fortune 500 companies' online sponsorship policies and mission statements was followed by cluster, factor and multinomial regression techniques. Results showed that corporate identity, as reflected in mission statements, matters to sponsorship policy. Specifically, companies emphasizing financial success in their mission statements prefer to sponsor individual athletes, education, the environment and health-related activities. Alternatively, companies stressing the importance of employees demonstrate a propensity to sponsor team sports, entertainment, religious, community, charity and business related activities. (2) 
Using the Psychological Continuum Model (PCM) as the theoretical framework, Filo, K., Funk, D., \& O'Brien, D. (2010) examined the factors that contribute to participants' perceptions of event sponsors. The influence of this image of event sponsors on behavioral outcomes among participants is also investigated. A post-event questionnaire was administered to participants in a sport event $(\mathrm{N}=672)$ to investigate the relationships among motives, sponsor image, event attachment, purchase intent, and future participation intent. Results reveal that recreation and charity motives contribute to event attachment, while charity motives and event attachment contribute to sponsor image. Significantly, sponsor image and attachment contributed to purchase intent for event sponsors' products. Finally, sponsor image did not influence future participation intent, while event attachment did. The results illustrated the discrete roles that sponsor image and attachment play in sport consumption activities. (7)

\section{Research Importance:}

This research is very important for sponsors and sponsees as well, the importance of sponsorship ROI research for sponsors is to make better strategic sponsorship decisions and also to achieve sales, financial and non-financial targets, as well as to negotiate rights acquisition fees and set activation budgets, moreover, it is crucial to deliver long-term brand equity and value.

On the other hand, for properties and rights holders too, there are important benefits from sponsorship ROI measurement and evaluation research such as justifying healthy rights fees in order to have better understanding and work with brand sponsors, also to expand the pool of brands who can use sponsorship effectively, as well as to make better strategic sponsorship decisions in order to renew sponsorship partnerships successfully. Generally, properties that can show they deliver for brands will continue to be successful attracting sponsors.

\section{Aim:}

The current research aims to identify and analyze the sponsorship return on investment ROI for sponsors in the field of sport in Egypt 
through the eyes of those who invest in the Egyptian sport property (sponsors) and those that are hold the brand and sponsorship (sponsees) and also those who used to play a mediating role (sport marketing agencies) which impacting the sport sponsorship in Egypt to encourage them to spend more money and increase their sponsorship

programs/activities toward Egyptian sport.

\section{Research Questions:}

To achieve the research aim, the research poses the following four questions:

1. Do sponsorship activities/programs create more sales/revenues for sponsors in the field of sport?

2. Do sponsorship activities/programs improve Brand loyalty/ Brand image/ Customer satisfaction with existing customers?

3. What is the overall financial ROI for sponsors in the field of sport?

4. How do sponsorship activities/programs impact the overall ROI for sponsors in the field of sport?

Methods:

Approach:
The researcher used the descriptive (survey) approach as it is suitable for the purposes of this research.

Participants:

The research community included board members and marketing personnel of two sports clubs (Al-Ahly and AlZamalek) and four Egyptian sports federations (Football Basketball - Tennis and Table Tennis) in addition marketing personnel of five sponsoring companies (Vodafone Egypt - Etisalat Egypt - Pepsi - Juhaina Ceramica Cleopatra) as official sponsors of sports activities. $(\mathrm{n}=90)$

The main research sample $(n=30)$ was randomly selected including (20) board members and marketing personnel of sports clubs and federations in addition to (10) marketing personnel representing sponsors. This makes the final number of research sample (30) persons. Another (12) persons from the same research community and outside the main sample were included as a pilot sample for validating the research tool (appendix 3). Data Collection Tool:

For the purposes of this research, the researcher 
developed the Return on Investment Questionnaire (ROI-Q). The questionnaire included (3) axes with (6) items under each axis. To develop the questionnaire, the researcher reviewed related literature on the topic of sponsorship and investment (1, $5,7,8,9,10,11)$ and presented the axes to a group of experts in sports administration $(\mathrm{n}=7)$ (annex 1). After that, the researcher developed a draft of items for the questionnaire and presented it to experts $(n=7)$ to identify their opinions about the questionnaire. Tables (1) and (2) show experts' opinions about the axes and items of the questionnaire.

Table (1)

experts opinions about the axes of the ROI-Q questionnaire (n=7)

\begin{tabular}{|c|c|c|c|c|c|c|c|}
\hline & \multirow{2}{*}{ Axes } & \multicolumn{2}{|c|}{ Agree } & \multicolumn{2}{|c|}{ Disagree } & \multirow{2}{*}{$\begin{array}{c}\text { Relative } \\
\text { weight }\end{array}$} & \multirow{2}{*}{$\begin{array}{c}\text { Relative } \\
\text { importance }\end{array}$} \\
\hline & & $\mathrm{F}$ & $\%$ & $\mathrm{~F}$ & $\%$ & & \\
\hline 1 & $\begin{array}{ll}\text { Role } & \text { of } \\
\text { sponsorship } & \text { in } \\
\text { increasing } & \\
\text { sponsors' } & \\
\text { revenues. } & \\
\end{array}$ & v & $1 \ldots$. & $\cdot$ & $\because \cdots$ & V & $1 \ldots$ \\
\hline r & \begin{tabular}{|lr} 
Role & of \\
sponsorship & in \\
improving the \\
brand \\
sponsors
\end{tabular} & V & $1 \ldots$. & $\cdot$ & $\because \cdots$ & V & $1 \ldots$ \\
\hline$r$ & $\begin{array}{ll}\text { Role } & \text { of } \\
\text { sponsorship in } \\
\text { increasing } \\
\text { customers' } \\
\text { satisfaction } \\
\text { towards } \\
\text { sponsors' } \\
\text { products }\end{array}$ & V & $1 \ldots \ldots$ & . & $\because \cdots$ & V & $1 \ldots \ldots$ \\
\hline
\end{tabular}

Table (1) indicates that the agreement percentage of experts about the axes of ROI-Q questionnaire was (100\%).

Table (2) 
experts opinions about the items of the ROI-Q questionnaire $(n=7)$

\begin{tabular}{|c|c|c|c|c|c|}
\hline \multicolumn{2}{|c|}{ First Axis } & \multicolumn{2}{|c|}{ Second Axis } & \multicolumn{2}{|c|}{ Third Axis } \\
\hline $\mathbf{S}$ & $\begin{array}{c}\text { Agreement } \\
\text { percentage } \\
(\%)\end{array}$ & $\mathbf{S}$ & $\begin{array}{l}\text { Agreement } \\
\text { percentage } \\
(\%)\end{array}$ & $\mathbf{S}$ & $\begin{array}{l}\text { Agreement } \\
\text { percentage } \\
(\%)\end{array}$ \\
\hline 1 & A०.VI & $\Lambda$ & A०.VI & 17 & A०.VI \\
\hline$r$ & $1 \ldots$ & 9 & 10.VI & $1 \mathrm{~V}$ & $1 \cdots$ \\
\hline$\mu$ & $1 \cdots \cdots$ & 1 . & 10.VI & 11 & NO.VI \\
\hline$\varepsilon$ & YA.OV & 11 & $1 \leqslant .49$ & 19 & TA.OV \\
\hline 0 & $1 \cdots$ & IT & A०.VI & T. & $1 \ldots$ \\
\hline 7 & $1 \ldots$ & $\pi$ & $1 \ldots$ & YI & AO.VI \\
\hline$V$ & $1 \ldots \ldots$ & $1 \varepsilon$ & $1 \varepsilon .4 q$ & TY & $1 \ldots$ \\
\hline 8 & & 10 & $1 \cdots$ & & \\
\hline
\end{tabular}

Table (2) indicates that the agreement percentages of experts about the items of ROIQ questionnaire ranged between (14.29\%) and (100\%). All items below (71.43\%) were excluded from the questionnaire.

The preliminary version of ROI-Q questionnaire included (22) items distributed on (3) axes. After consulting experts, this number was reduced to (18) items distributed on (3) axes. Table (3) shows the preliminary number of items, final number of items and numbers of excluded items according to experts' opinions.

Table (3)

preliminary number of items, final number of items and numbers of excluded items for ROI-Q questionnaire

\begin{tabular}{|c|c|c|c|c|c|c|c|}
\hline$\overline{\mathbf{S}}$ & Axes & $\begin{array}{c}\text { Preliminary } \\
\text { number of } \\
\text { items }\end{array}$ & $\begin{array}{l}\text { Excluded } \\
\text { items }\end{array}$ & $\begin{array}{c}\text { Numbers } \\
\text { of } \\
\text { excluded } \\
\text { items }\end{array}$ & $\begin{array}{l}\text { Modified } \\
\text { items }\end{array}$ & $\begin{array}{c}\text { Numbers } \\
\text { of } \\
\text { modified } \\
\text { items }\end{array}$ & $\begin{array}{c}\text { Final } \\
\text { number } \\
\text { of items }\end{array}$ \\
\hline & is & V & 1 & $\varepsilon$ & . & . & 7 \\
\hline & xis & $\wedge$ & r & 10.11 & . & . & 7 \\
\hline \multirow[t]{2}{*}{ r } & $\begin{array}{l}\text { Thir } \\
\text { d } \\
\text { axis }\end{array}$ & V & 1 & 19 & . & . & 7 \\
\hline & Total & KY & $\varepsilon$ & $\varepsilon$ & . & . & 11 \\
\hline
\end{tabular}

Table (3) indicates that the questionnaire included preliminary version of ROI-Q items distributed on (3) axes. 
After consulting experts, this number was reduced to (18) items distributed on (3) axes (6 items each).

Validity and Reliability of ROI-Q Questionnaire:

After reaching the final version of the ROI-Q questionnaire, the researcher applied the final version to a pilot sample $(n=12)$ from the same research community and outside the main sample to calculate its validity and reliability.

Table (4)

Correlation Coefficients between each item and its axis and each item and the total score of the ROI-Q questionnaire $(n=12)$

\begin{tabular}{|c|c|c|c|c|c|c|c|c|}
\hline \multicolumn{3}{|c|}{ First Axis } & \multicolumn{3}{|c|}{ Second Axis } & \multicolumn{3}{|c|}{ Third Axis } \\
\hline $\mathbf{S}$ & $\begin{array}{l}\text { Item } \\
\text { with } \\
\text { axis }\end{array}$ & $\begin{array}{l}\text { Item } \\
\text { with } \\
\text { total }\end{array}$ & $\mathbf{S}$ & $\begin{array}{l}\text { Item } \\
\text { with } \\
\text { axis }\end{array}$ & $\begin{array}{l}\text { Item } \\
\text { with } \\
\text { total }\end{array}$ & $\mathbf{S}$ & $\begin{array}{l}\text { Item } \\
\text { with } \\
\text { axis }\end{array}$ & $\begin{array}{l}\text { Item } \\
\text { with } \\
\text { total }\end{array}$ \\
\hline 1 &.$\wedge \varepsilon$ & $\overline{l . \wedge \wedge}$ & $\bar{V}$ & $\overline{l \cdot \Delta r}$ & .91 & $1 \pi$ & .9. & .99 \\
\hline$r$ &.$\wedge \Gamma$ & $\because \wedge V$ & $\Lambda$ & $\because \wedge \wedge$ & $\because \vee \wedge$ & $1 \leq$ & .94 &.$\wedge 9$ \\
\hline$r$ & .91 & $\cdot . \wedge r$ & 9 & $\cdot .9 Y$ &.$\wedge 7$ & 10 &.$\wedge 7$ & $.9 r$ \\
\hline$\varepsilon$ & $\cdot \wedge$. & $\cdot . \wedge 9$ & 1. &.$\wedge Y$ &.$\wedge V$ & 17 & $.9 Y$ &.$\wedge 7$ \\
\hline 0 & .19 &.$\wedge \varepsilon$ & 11 & $\cdot \wedge \mathrm{V}$ & .99 & IV & $\cdot . \wedge \mathrm{V}$ & .10 \\
\hline 7 & $\cdot . \wedge r$ & $\cdot . \wedge T$ & IT &.$V T$ &.$\wedge \varepsilon$ & 11 & $\cdot . \wedge \wedge$ & $.9 r$ \\
\hline $\begin{array}{l}\mathrm{R} \mathrm{t} \\
\text { stat } \\
\text { cor } \\
\text { and } \\
\text { the }\end{array}$ & $\begin{array}{r}\text { le valu } \\
\text { Table } \\
\text { tically } \\
\text { lations } \\
\text { ts axis } \\
\text { total }\end{array}$ & $\begin{array}{c}0.05 \\
\text { (4) }\end{array}$ & $\begin{array}{l}=0.5 \\
\text { indi } \\
\text { gnif }\end{array}$ & $\begin{array}{l}\text { tes } \\
\text { ant } \\
\text { em } \\
\text { and } \\
\text { the }\end{array}$ & $\begin{array}{l}\text { quest } \\
\text { value } \\
\text { value } \\
\text { indic } \\
\text { quest } \\
\text { interr }\end{array}$ & $\begin{array}{l}\text { nair } \\
\text { exc } \\
\text { on }\end{array}$ & $\begin{array}{l}\text { as }(\mathrm{R}) \\
\mathrm{ded} \\
\mathrm{P} \leq 0.0 \\
\text { it the } \\
\text { has } \\
\text { tency. }\end{array}$ & $\begin{array}{r}\text { talated } \\
\text { table } \\
\text { This } \\
\text { ROI-Q } \\
\text { high }\end{array}$ \\
\hline
\end{tabular}


Table (5)

Correlation coefficient between each axis and the total score of the ROI-Q questionnaire $(n=12)$

\begin{tabular}{|c|c|c|}
\hline $\mathbf{S}$ & Axes & $\mathbf{R}$ \\
\hline 1 & $\begin{array}{l}\text { Role of sponsorship in increasing sponsors' } \\
\text { revenues. }\end{array}$ & $\cdot \wedge \wedge$ \\
\hline T & $\begin{array}{l}\text { Role of sponsorship in improving the brand } \\
\text { of sponsors }\end{array}$ & .94 \\
\hline$\Gamma$ & $\begin{array}{l}\text { Role of sponsorship in increasing } \\
\text { customers' satisfaction towards sponsors' } \\
\text { products }\end{array}$ & .91 \\
\hline
\end{tabular}

$R$ table value on $0.05=0.57$

Table (5) indicates statistically significant correlations between each axis and the total score of the ROI$\mathrm{Q}$ questionnaire as (R) calculated values exceeded its table values on $\mathrm{P} \leq 0.05$. This indicates that the ROI-Q questionnaire has a high internal consistency.

Reliability:
To calculate the ROI-Q questionnaire reliability, the research used test/retest procedure on a pilot sample of (12) persons from the same research community and outside the main sample. Table (6) shows correlation coefficients between test and retest of the ROI-Q questionnaire items.

Table (6)

correlation coefficients between test and retest of the ROI-Q questionnaire $(n=12)$

\begin{tabular}{|c|c|c|c|c|c|}
\hline \multicolumn{2}{|c|}{$\overline{\text { First Axis }}$} & \multicolumn{2}{|c|}{ Second Axis } & \multicolumn{2}{|c|}{ Third Axis } \\
\hline $\bar{S}$ & $\overline{\mathrm{R}}$ & $\bar{S}$ & $\overline{\mathrm{R}}$ & $\overline{\mathrm{S}}$ & $\overline{\mathrm{R}}$ \\
\hline 1 & .91 & $\mathrm{~V}$ &. .19 & 14 & .199 \\
\hline$r$ & $\cdot . \wedge 7$ & $\wedge$ & .94 & $1 \varepsilon$ &.$\wedge V$ \\
\hline$r$ & $\cdot \wedge \varepsilon$ & 9 & .91 & 10 & .199 \\
\hline$\varepsilon$ & $\cdot \wedge \wedge$ & 1. & .10 & 17 & .94 \\
\hline 0 & .91 & 11 &.$\wedge \varepsilon$ & IV & .9 \\
\hline 7 & $\cdot \wedge V$ & Ir & .9 . & 11 & .19 \\
\hline
\end{tabular}

$\mathrm{R}$ table value on $0.05=0.57$ 
Table statistically correlation between test and retest of the ROI-Q questionnaire items as (R) calculated values ranged between (0.84) and (0.93) and this exceeds its table value.

Table (7) : Cronbach's Alpha for the three axes of the ROI_Q questionnaire $(n=12)$

\begin{tabular}{|c|c|c|}
\hline \multicolumn{3}{|c|}{ Cronbach's Alpha } \\
\hline \multicolumn{3}{|c|}{$.9 \pi$} \\
\hline $\bar{S}$ & Axes & Cronbach's Alpha \\
\hline 1 & $\begin{array}{l}\text { Role of sponsorship in increasing } \\
\text { sponsors' revenues. }\end{array}$ &.$\wedge 9$ \\
\hline r & $\begin{array}{l}\text { Role of sponsorship in improving the } \\
\text { brand of sponsors }\end{array}$ & .9 \\
\hline$r$ & $\begin{array}{l}\text { Role of sponsorship in increasing } \\
\text { customers } \begin{array}{r}\text { satisfaction } \\
\text { towards } \\
\text { sponsors' products }\end{array}\end{array}$ & $\cdot \wedge \wedge$ \\
\hline
\end{tabular}

\section{Table (8)}

Cronbach's Alpha for the ROI_Q questionnaire (n=12)

\begin{tabular}{c|c|c}
\hline \hline$S$ & Questionnaire & Correlation coefficient \\
\hline \hline 1 & ROI-Q & $\cdot .9 \mathrm{r}$ \\
\hline \hline
\end{tabular}

The values shown in tables (7) and (8) indicate that the questionnaire is highly reliable.

Pilot Study:

The researcher applied the final version of the ROI-Q questionnaire to a pilot sample $(\mathrm{n}=12)$ from 1-9-2012 to 7-92012 to fulfill the following objectives:
In addition, the researcher calculated Cronbach's Alpha for the three axes of the ROI_Q questionnaire as shown in tables (7) and (8). 
items easily. Time needed for answering the questionnaire was (30) minutes.

\section{Main application:}

The researcher applied the final version of the ROI-Q questionnaire on the main sample $(\mathrm{n}=30)$ from 8-9-2012 to 28-9-2012. Each participant received a copy of the questionnaire at his/her workplace. All participants were asked to answer frankly all the questions through choosing the best answer as their opinion. After application, the researcher corrected the questionnaire according a three-point likert scale as yes $=3$, somehow $=2$ and no $=1$. Data was tabulated for statistical treatment.

\section{Statistical treatment:}

The researcher used SPSS software to calculate the following: frequency percentage - relative importance - relative weight $\mathrm{CHI}^{2}$ - correlation coefficient Cronbach's Alpha.

\section{Results:}

Concerning the first axis "Role of sponsorship in increasing sponsors' revenues", table (9) shows the frequency, percentage, relative importance, relative weight and $\mathrm{CHI}^{2}$ of participants' opinions.

Table (9): frequency, percentage, relative importance, relative weight and $\mathrm{CHI}^{2}$ of participants' opinions for the first axis "Role of sponsorship in increasing sponsors' revenues" $(n=30)$

\begin{tabular}{|c|c|c|c|c|c|c|c|c|c|c|}
\hline \multirow[b]{2}{*}{$\mathbf{S}$} & \multirow[b]{2}{*}{ Item } & \multicolumn{2}{|c|}{ Yes } & \multicolumn{2}{|c|}{ Somehow } & \multicolumn{2}{|c|}{ No } & \multirow{2}{*}{$\begin{array}{c}\text { Relative } \\
\text { weight }\end{array}$} & \multirow{2}{*}{$\begin{array}{c}\text { Relative } \\
\text { Importance }\end{array}$} & \multirow[b]{2}{*}{$\mathrm{CHI}^{2}$} \\
\hline & & $\mathbf{F}$ & $\%$ & $\mathbf{F}$ & $\%$ & $\mathbf{F}$ & $\%$ & & & \\
\hline 1 & 1 & $\overline{r \wedge}$ & $\overline{q \mu . r T}$ & $\bar{r}$ & $7.7 V$ & . & $\because \cdots$ & $\wedge \wedge$ & $\overline{q \vee . \vee \wedge}$ & $\varepsilon \wedge . \wedge$. \\
\hline$r$ & r & YT & AT. TV & $\varepsilon$ & שr.Tו & . & $\because \cdots$ & $\Lambda 7$ & 90.07 & rq.r. \\
\hline$r$ & $r$ & $r \cdot$ & $1 \ldots . \cdots$ & $\cdot$ & $\because \cdots$ & $\cdot$ & $\because \cdots$ & 9. & $1 \cdots \ldots$ & $7 .$. \\
\hline$\varepsilon$ & $\varepsilon$ & $r \wedge$ & qr.rT & $r$ & $7.7 V$ & $\cdot$ & $\because \cdots$ & $\Lambda \Lambda$ & $9 \vee . \vee \wedge$ & $\varepsilon \wedge . \wedge$. \\
\hline 0 & 0 & 11 & $7 . . \cdots$ & 1. & TrT & $r$ & $7.7 \mathrm{~V}$ & $V 7$ & $\Lambda \leq . \leq \varepsilon$ & IT.A. \\
\hline 7 & 7 & $r \cdot$ & $77.7 V$ & $r$ & $1 \ldots$ & V & rזrזr & $V T$ & 11.11 & 10.1. \\
\hline
\end{tabular}

$\mathrm{CHI}^{2}$ table value on $0.05=5.99$

Table (9) indicates that the relative weight values ranged between (73) for item (6) and (90) for item (3), while relative importance values ranged between (81.11) for item (6) and (100) for item (3).
$\mathrm{CHI}^{2}$ values ranged between (12.80) and (60) and were all above its table value (5.99) on $\mathrm{P} \leq 0.05$.

Concerning the second axis "Role of sponsorship in improving the brand of 
sponsors", table (10) shows the importance, relative weight and frequency, percentage, relative $\mathrm{CHI}^{2}$ of participants' opinions.

Table (10): frequency, percentage, relative importance, relative weight and $\mathrm{CHI}^{2}$ of participants' opinions for the second axis

"Role of sponsorship in improving the brand of sponsors" (n=30)

\begin{tabular}{|c|c|c|c|c|c|c|c|c|c|c|}
\hline \multirow[b]{2}{*}{$\mathbf{S}$} & \multirow[b]{2}{*}{ Item } & \multicolumn{2}{|c|}{ Yes } & \multicolumn{2}{|c|}{ Somehow } & \multicolumn{2}{|c|}{ No } & \multirow{2}{*}{$\begin{array}{c}\text { Relative } \\
\text { weight }\end{array}$} & \multirow{2}{*}{$\begin{array}{c}\text { Relative } \\
\text { Importance }\end{array}$} & \multirow[b]{2}{*}{$\mathrm{CHI}^{2}$} \\
\hline & & $\mathbf{F}$ & $\%$ & $\mathbf{F}$ & $\%$ & $\mathbf{F}$ & $\%$ & & & \\
\hline 1 & $\bar{V}$ & rA & & $\bar{r}$ & $7.7 V$ & . & $\because \cdots$ & $\Lambda \Lambda$ & $9 \vee . \vee \wedge$ & $\leqslant \wedge . \wedge$. \\
\hline$r$ & $\Lambda$ & rA & q4.Tr & $r$ & $7.7 \mathrm{~V}$ & $\cdot$ & $\because \cdots$ & $\Lambda \wedge$ & qV.VA & $\varepsilon \wedge . \wedge$. \\
\hline$\mu$ & 9 & rA & & $r$ & $7.7 V$ & . & $\because \cdots$ & $\Lambda \wedge$ & $9 \vee . \vee \wedge$ & $\Sigma \wedge . \wedge$. \\
\hline$\varepsilon$ & 1. & YI & $v \cdot \ldots$ & $\cdot$ & $\because \cdots$ & 9 & $r \cdot \cdots$ & VY & $\Lambda \cdot \cdots$ & YT.Y. \\
\hline 0 & 11 & rI & $V \cdot \ldots$ & $\Lambda$ & Y7. VV & 1 & r.M & $\Lambda$. & $\wedge \wedge . \wedge 9$ & $r .7$. \\
\hline 7 & IT & ro & 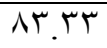 & $\varepsilon$ & Tr.T & 1 & אזיז & $\Lambda \varepsilon$ & qr.r. & TE.T. \\
\hline
\end{tabular}

$\mathrm{CHI}^{2}$ table value on $0.05=5.99$

Table (10) indicates that the relative weight values ranged between (77) for item (4) and (88) for items (1, 2 and $3)$, while relative importance values ranged between (80) for item (4) and (97.78) for items (1, 2 and 3$). \mathrm{CHI}^{2}$ values ranged between (20.60) and

(48.80) and were all above its table value (5.99) on $\mathrm{P} \leq 0.05$.

Concerning the third axis "Role of sponsorship in increasing customers' satisfaction towards sponsors' products", table (11) shows the frequency, percentage, relative importance, relative weight and CHI2 of participants' opinions

Table (11): frequency, percentage, relative importance, relative weight and CHI2 of participants' opinions for the third axis "Role of sponsorship in increasing customers' satisfaction towards sponsors' products" $(\mathrm{n}=\mathbf{3 0})$

\begin{tabular}{|c|c|c|c|c|c|c|c|c|c|c|}
\hline \multirow[b]{2}{*}{$\mathbf{S}$} & \multirow[b]{2}{*}{ Item } & \multicolumn{2}{|c|}{ Yes } & \multicolumn{2}{|c|}{ Somehow } & \multicolumn{2}{|r|}{ No } & \multirow{2}{*}{$\begin{array}{c}\text { Relative } \\
\text { weight }\end{array}$} & \multirow{2}{*}{$\begin{array}{c}\text { Relative } \\
\text { Importance }\end{array}$} & \multirow[b]{2}{*}{$\mathrm{CHI}^{2}$} \\
\hline & & $\mathbf{F}$ & $\%$ & $\mathbf{F}$ & $\%$ & $\mathbf{F}$ & $\%$ & & & \\
\hline 7 & $\pi$ & $\overline{r \wedge}$ & r.r.r. & $\bar{r}$ & $7.7 \mathrm{~V}$ & - & $\because \cdots$ & $\overline{\lambda \Lambda \Lambda}$ & qV.V^ & 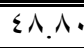 \\
\hline T & $1 \varepsilon$ & rA & $q \pi . r 4$ & r & $7.7 \mathrm{~V}$ & . & $\because \cdots$ & $\Lambda \wedge$ & $9 \vee . V \wedge$ & $\varepsilon \wedge . \wedge$. \\
\hline$r$ & 10 & 19 & אז.זד & 1. & זיז.זr & 1 & r.r & $\vee \wedge$ & ง५. . V & 17.4. \\
\hline$\varepsilon$ & 17 & 17 & س.r.ror & $\Lambda$ & Y..TV & 7 & $r . .$. & $V$. & $\checkmark \vee . \vee \wedge$ & 0.7. \\
\hline 0 & IV & 17 & r.r. & $\Lambda$ & Y7.TV & 7 & $r \cdot \ldots$ & $V \cdot$ & $\checkmark \vee . \vee \wedge$ & 0.7. \\
\hline 7 & 11 & YI & $v \cdot \ldots$ & 7 & $r \cdot \ldots$ & $r$ & $1 \ldots$ & $\vee \wedge$ & A. $7 \mathrm{~V}$ & 11.7. \\
\hline
\end{tabular}

$\mathrm{CHI}^{2}$ table value on $0.05=5.99$ 
Table (11) indicates that the relative weight values ranged between (70) for items (4 and 5) and (88) for items (1 and 2), while relative importance values ranged between (77.78) for item (4 and 5) and (97.78) for items (1 and 2). $\mathrm{CHI}^{2}$ values ranged between (5.60) and (48.80) and were all above its table value (5.99) on $\mathrm{P} \leq 0.05$.

\section{Discussion:}

Concerning the first axis "Role of sponsorship in increasing sponsors' revenues", table (9) shows that the relative weight values ranged between (73) for item (6) and (90) for item (3), while relative importance values ranged between (81.11) for item (6) and (100) for item (3). $\mathrm{CHI}^{2}$ values ranged between (12.80) and (60) and were all above its table value (5.99) on $\mathrm{P} \leq 0.05$.

From these results, the researcher thinks that the most important motive of sponsors to confirm sponsorship deals is the tax cuts they enjoy due to these deals. In addition, sponsors gain clear investment revenues and promote their goods well through such deals. Furthermore, sponsorship deals improve sales and decrease stagnant goods while marginally improving retail sales.

This is consistent with Cornwell et al (2001), Farrelly et al (2006), Filo et al (2010) and Henseler (2011) who indicated that investment bonus like tax cuts may help encouraging investors to involve in sponsorship deals in the field of sport. $(1,5,7$ and 8)

In addition, Kim (2010), Long et al (2004) and Mullin et al (2000) indicated that sponsors and investors seek to improve their sales through giving their goods a prominent place in the media coverage as this policy improves their return on investment clearly. (11, 13 and 16)

Tsiotsou, R. \& Alexandris (2009) and Stotlar (1999) indicated that sponsorship campaigns work effectively on improving the return on investment through promoting stagnant goods, improving sales and increasing brand announcement.

Concerning the second axis "Role of sponsorship in improving the brand of sponsors", table (10) shows that the relative weight values ranged between (77) for item 
(4) and (88) for items (1, 2 and 3 ), while relative importance values ranged between (80) for item (4) and (97.78) for items (1, 2 and 3 ). $\mathrm{CHI}^{2}$ values ranged between (20.60) and (48.80) and were all above its table value (5.99) on $\mathrm{P} \leq 0.05$.

The researcher thinks that working on brand improvement is very important for investors to increase their revenues. These efforts should be consistent with the policies developed by investors to improve their investment return. One of the most powerful tools in doing so is sponsorship campaigns. Results indicated that sponsorship campaigns reactivate the brand name of a sponsor, help spreading this brand name and improve sales greatly. Furthermore such sponsorship campaigns improve the value of brand names through stabilizing, and even increasing, sales rates.

Irwin et al (1994), John Rowady (2010) and Kim (2010) indicated that improving the brand name of the product is very beneficial for improving its revenues. When a sponsorship campaign is conducted effectively it provides positive effects as it facilitates the sales of products directly related to the sponsor's brand name. These sales improve the sales rates which in turn improve the value of the brand name. (9, 10 and 11)

Lee \& Cho (2009), Mullin et al (2000) and Olkkonen (2001) also indicated that successful sponsorship campaigns really improve the sponsor's brand name through spreading it and improving its value. The return on investment in this case is clearly increasing as the main outcome measure, which is the increased sales rate, improves markedly (12, 16 and 17)

Concerning the third axis "Role of sponsorship in increasing customers' satisfaction towards sponsors' products", table (11) shows that the relative weight values ranged between (70) for items (4 and 5) and (88) for items (1 and 2), while relative importance values ranged between (77.78) for item (4 and 5) and (97.78) for items (1 and 2). $\mathrm{CHI}^{2}$ values ranged between (5.60) and (48.80) and were all above its table value (5.99) on $\mathrm{P} \leq 0.05$.

The researcher thinks that the main objective of sponsorship campaigns is to 
increase current customers' satisfaction about the product. In addition, successful sponsorship campaigns work on increasing the number of potentials customers as this will increase the return on investment. This needs specific efforts on measuring customers' satisfaction rates about the products and the campaigns themselves. Cunningham et al (2009), Farrelly et al (2003 a \& b) and Farrelly et al (2005) indicated that the brand image is improved greatly through sponsorship campaigns and this improvement leads to increasing the customers' satisfaction and the number of potential customers. (2, 3, 4 and 6)

Pressey \& Mathews (2003) and Seguin and O'Reilly (2007) indicated that measuring customers' satisfaction about the sponsorship campaign is of major importance as the campaign performance affects its outcomes greatly. In addition, they agreed that increasing the current customers' satisfaction level may increase the number of potential customers in the near future. They also think that sponsorship campaigns work on improving the brand names of sponsors in the eyes of customers (18 and 19).

\section{Conclusions:}

In the light of this research aim, questions, methodology and results, the researcher managed to conclude the following:

1. The most important benefits of sponsorship campaigns for investors are tax cuts, improving sales, decreasing stagnant goods and improving brand names.

2. Successful sponsorship campaigns improve sales of products related to the sponsorship campaign

3. Successful sponsorship campaigns improve the brand name value of the sponsor.

4. Successful sponsorship campaigns improve the image of products in the eyes of customers

5. Successful sponsorship campaigns improve customers' satisfaction levels about the products.

6. Successful sponsorship campaigns improve the number of potential customers

7. Successful sponsorship campaigns have clear return on investment for sponsors and investors.

\section{Recommendations:}

According to this research results and conclusions, the researcher recommends the following:

1. Sponsors and investors should be informed about the benefits sponsorship campaigns in improving the return on investment. 
2. Effectiveness of sponsorship campaigns should be measured and modified periodically.

3. It is very important to measure the customers' satisfaction about the products included in sponsorship campaigns.

4. It is very important to measure the customers' satisfaction about the performance of sponsorship campaigns

References:

1- Cornwell, B., Roy, D.P., \& Steinard, E.A., II. (2001). Exploring managers' perceptions of the impact of sponsorship on brand equity. Journal of Advertising, 30(2), 41-52.

2-Cunningham, S., Cornwell, T. B., \& Coote, L. V. (2009). Expressing identity and shaping image: The relationship between corporate mission and corporate sponsorship. Journal of Sport Management, 23(1), 65-86.

3- Farrelly, F., \& Quester, P. (2003a). Understanding the sponsorship principal/agent relationship. Journal of Advertising Research, 43(4), 1-9.

4- Farrelly, F., \& Quester, P. (2003b). The effects of market orientation on trust and commitment: the case of the sponsorship business-tobusiness relationship. European Journalof Marketing, 37(3/4), 530-553.
5- Farrelly, F., Quester, P., \& Burton, R. (2006). Changes in sponsorship value: Competencies and capabilities of successful sponsorship relationships. Industrial Marketing Management,35, 1016-1027.

6- Farrelly, F., Quester, P., \& Greyser, S. (2005). Defending the co-branding benefits of sponsorship in B2B partnerships: The case of ambush marketing. Journal of AdvertisingResearch, 45(3), 31-39.

7- Filo, K., Funk, D., \& O'Brien, D. (2010). The antecedents and outcomes of attachment and sponsor image within charity sport events. Journal of Sport Management, 24(6), 623-648.

8- Henseler. .J. Wilson. $B$ and Westberg, K 2011, 'Managers' perceptions of the impact of sport sponsorship on brand equity: Which aspects of the sponsorship

Most?', Sport Marketing Quarterly, vol. 20, no. 1, pp. 721.

9- Irwin, R.L., Assima kopoulos, M.L., \& Sutton, W.A. (1994). A model for screening sport sponsorship opportunities. Journal of Promotion Management, 2(3/4), 53-69.

10- John Rowady (2010) : Why Brands Need to Better Optimize the Value of Their Sponsorship ROI, AdvertisingAge, Retrieved 
from http://adage.com/article/ special- report- sportsmarketing- 2010/ brandsoptimize- $\quad$ sponsorship-roi /145070/ on December 23, 2012

11- Kim, J. W. (2010). The worth of sport event sponsorship: an event study. Journal of Management and Marketing Research, 5(1), 114.

12- Lee, H. S., \& Cho, C. H. (2009). The matching effect of brand and sporting event personality: Sponsorship implications. Journal of Sport Management,23(1), 41-64.

13- Long, J., Thibault, L., \& Wolfe, R. (2004). A case study of influence over a sponsorship decision in a Canadian university athletic department. Journal of Sport Management,18, 132-157.

14- Mason, D.S. (1999). What is the sports product and who buys it? The marketing of professional sports leagues. European Journal of Marketing, 33(3/4), 1-11.

15- McKelvey, S. And Grady, J. (2008). Sponsorship Program Protection Strategies for Special Sport Events: Are Event Organizers Outmaneuvering Ambush Marketers?, Journal of Sport Management, 22, 550-586
16- Mullin, B., Hardy, S., \& Sutton, W. (2000). Sport marketing. Champaign, IL: Human Kinetics.

17- Olkkonen, R. (2001). Case study: The network approach to international sport sponsorship arrangement. Journal of Business and Industrial Marketing, 16, 309327.

18- Pressey, A.D., \& Mathews, B.P. (2003). Jumped, pushed or forgotten? Approaches to termination Journal of Marketing Management, 19(1/2), 131155.

19- Seguin, B. And O'Reilly, N.J. (2007) 'The Olympic brand, ambush marketing and clutter', Int. J. Sport Management and Marketing, Vol. 22,NO. 2, PP 78-104.

20- Stotlar, D.K. (1999). Sponsorship in North America: A survey of sport executives. International Journal of Sports Marketing \& Sponsorship, 1(1), 87-100.

21- Tsiotsou, R., \& Alexandris, K. (2009). Delineating the outcomes of sponsorship: sponsor image, word of mouth, and purchase intentions. International Journal of Retail \& Distribution Management, 37 (4), 358-369. 